\title{
Importance, features and uses of metal oxide catalysts in heterogeneous catalysis
}

\author{
Jacques C. Védrine * \\ Sorbonne Université, Laboratoire de réactivité de surface, UMR-CNRS 7197, 4 place Jussieu. F-75252 Paris, France
}

\section{A R T I C L E I N F}

\section{Article history:}

Received 13 June 2018

Accepted 23 August 2018

Published 5 November 2019

\section{Keywords:}

Heterogeneous catalysis

Metal oxide catalyst

Preparation procedure

Acid-base reaction

Selective and total oxidation reaction

Photocatalysis

Environmental catalysis

Industrial process

\begin{abstract}
A B S T R A C T
This short review paper aims at assembling the present state of the art of the multiuses of metal oxides in heterogeneous catalysis, concerning liquid and gaseous phases of the reactant mixtures on solid catalysts. It includes the description of the main types of metal oxide catalysts, of their various preparation procedures and of the main reactions catalysed by them (acid-base type, selective and total oxidations, bi-functional catalysis, photocatalysis, biomass treatments, environmental catalysis and some of the numerous industrial applications). Challenges and prospectives are also discussed. (C) 2018, Dalian Institute of Chemical Physics, Chinese Academy of Sciences.
\end{abstract} Published by Elsevier B.V. All rights reserved.

\section{Introduction}

Catalysis plays a major role in chemical, physical and biological sciences. It has become, during the years, one of the most important fields in chemistry, as some $85 \%-90 \%$ of industrial processes include at least one catalytic step and, more recently, in environmental chemistry. The main role of a catalyst is to decrease the activation energy of a chemical reaction and, in a multiproduct reaction, to favour the most important one, i.e. to favour selectivity which is now a major concern to avoid at most the formation of unwanted by-products, even at the expense of the reaction activity.

Catalysis is important in the refinement of petroleum, in the manufacturing of synthetic fibres and plastics, in the production of many specialty chemicals, in the processing of foods, in the production of drugs and pharmaceutical compounds, etc. It helps in the decrease of atmospheric pollution, in the design of environmentally friendly catalytic technologies, and of new processes to generate energy, and it is considered as a pillar of green chemistry in the preservation of our environment. From the viewpoint of an academic scientist, catalysis is viewed as a cross-disciplinary field, including organometallic chemistry, physical chemistry, chemical engineering, surface science, solid-state chemistry, and theoretical/computational chemistry.

Among all catalysts and catalytic reactions, metal oxide catalysts and catalytic reactions are essential in most refining and petrochemical processes, in synthesizing specialty chemicals and more recently in improving environmental issues (depollution, high selectivity in reactions to avoid un-useful by-products). Metal oxide catlsysts became prominent in the mid-1950s, when they were found to effectively catalyse a wide variety of oxidation and acid-base reactions. In this review paper, major types of metal oxide catalysts and processes that use these catalysts are reviewed. I have decided to focus its content

* Corresponding author. Tel: +33-668536212 or +33-144275560; E-mail: jacques.vedrine@sorbonne-universite.fr DOI: 10.1016/S1872-2067(18)63162-6 | http://www.sciencedirect.com/science/journal/18722067 | Chin. J. Catal., Vol. 40, No. 11 , November 2019 
on heterogeneous catalysis (mainly gas/solid and liquid/solid), in heterogeneous media, using metal oxide-type catalysts, whatever bulk or supported catalysts. In other words, catalysis by metals, by multi-metallic catalysts, supported or bulk catalysts, or by carbons (graphene, carbides), sulfides, etc., is excluded, although they constitute a large part of the catalysis field, in particular for petroleum and petrochemicals.

Advanced research in catalysis with metal oxides has permitted the development of catalysts with high selectivity and with new preparation procedures. The performance of a solid catalyst relies on its grain size, shape, composition and preparation. New strategies for the preparation of metal oxide catalysts have resulted in the development of catalysts with single sites, that lead to $100 \%$ selectivity. The advent of nanoscience has promoted bottom-up over top-down strategies. Nanocrystals, with sizes of only a few nanometres, present the best catalytic efficiencies. However, the use of a support (silica, alumina, silica-alumina, carbons, etc.) could be important for the synergistic activation of substrates, electron conductivity enhancement in redox reactions, thermal conductivity enhancement for exo/endothermal reactions, etc. The activity, selectivity, resistance to deactivation, and ability for regeneration are the properties that characterise the usefulness of catalysts, and have been improved in the last fifty years by advanced research and by improved industrial processes in catalysis with metal oxides.

\section{Main metal oxide catalysts [1-4]}

Metal oxide catalysts are involved in majority of industrial catalytic processes. They include simple oxides, such as silica, alumina, clays, zeolites, titania, zirconia, $\mathrm{ZnO}$, and porous and mesoporous metal oxides, or complex oxides, such as polyoxometalates (POMs) of Keggin or Dawson type, phosphates (e.g., $(\mathrm{VO})_{2} \mathrm{P}_{2} \mathrm{O}_{7}, \mathrm{FePO}_{4}$, silica phosphoric acid (SPA)), multicomponent mixed oxides (molybdates, antimonates, tungstates, $\mathrm{MoVTe}(\mathrm{Sb}) \mathrm{Nb}-\mathrm{O}$, etc.), perovskites, and hexaaluminates. Some of them correspond to specific arrangements of $\mathrm{MO}_{6}(\mathrm{M}=\mathrm{Mo}, \mathrm{V}, \mathrm{Te}, \mathrm{Nb}$, etc.) octahedra as schematised in Fig. 1.

These metal oxides present specific properties such as acidity (Lewis or/and Brønsted types), basicity, redox features (when transition metal ions are present), which lead to specific catalytic properties. They are also the basis for metallic (monoor pluri-metallic) catalysts, for hydrodesulfuration (HDS) catalysts $\left(\mathrm{CoMoO}_{4}-\right.$, $\mathrm{NiMoO}_{4}-$, $\mathrm{NiWO}_{4}$-based), for deNO $\mathrm{N}_{\mathrm{x}}$ and $\mathrm{deSO}_{\mathrm{x}}$ reactions, as perovskites or ceria-based doped oxides. The main catalytic domains cover oxidation (selective or total), acid and base catalysis, photocatalysis, depollution and biomass conversion. Metal oxides are sometimes used simply as supports of active phases, such as silica, alumina, silica-alumina, mesoporous oxides, MOFs, etc., which may influence catalytic properties due to synergistic, electron conductivity or/and thermal conductivity effects, which stem from metal oxide-support interactions.

Metal oxides [1] constitute a class of inorganic materials, which exhibit peculiar and various properties and applications

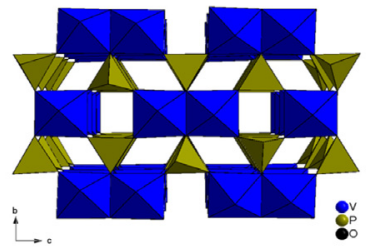

(a)

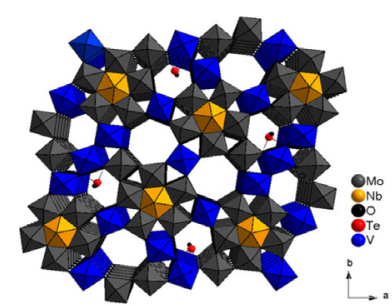

(c)

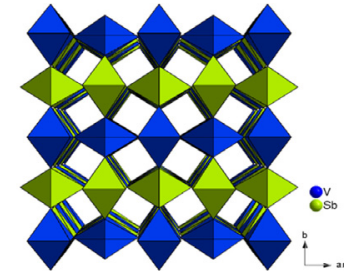

(b)

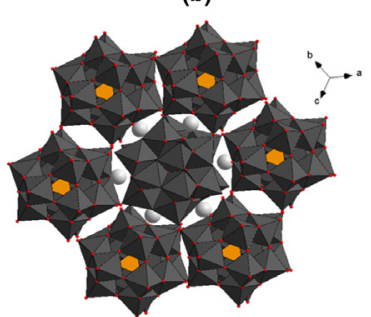

(d)
Fig. 1. Structures (composed of $\mathrm{MO}_{6}$ octahedra) of the most studied catalysts in alkane partial oxidation. (a) Vanadyl pyrophosphate (VPO); (b) VSbO rutile phase; (c) M1 phase, MoVTe(Sb)NbO; (d) Keggin molybdophophoric acid.

as sensors, catalysts, fuel cells, etc. Metal oxide surfaces terminate by oxygen $\mathrm{O}^{2-}$ anions, whose size is larger than that of $\mathrm{M}^{n+}$ cations. It follows that the symmetry, coordination and accessibility to reactant molecules of $\mathrm{M}^{n+}$ cations are lost at the surface. Moreover, the surface of an oxide may contain different types of defects and environments (kinks, steps, terraces), which may play a role in the catalytic phenomenon, for instance resulting in structure sensitivity of mletal oxides to catalytic reactions [5,6]. This surface unsaturation is usually compensated by a reaction with water vapour, leading to the formation of surface hydroxyls according to $\mathrm{O}^{2-}+\mathrm{H}_{2} \mathrm{O} \rightarrow 2 \mathrm{OH}^{-}$. These $\mathrm{OH}$ groups are conjugated acids of lattice oxygen ions $\mathrm{O}^{2-}$, which are strong bases and conjugated bases of water molecules.

Single or complex metal oxides based on the first transition series present a wide variety of non-stoichiometric phenomena, which originate from the unfilled $3 d$ electron shell. For instance, $\mathrm{Fe}$ sites can be vacant in $\mathrm{FeO}$ of rocksalt framework $\left(\mathrm{Fe}_{1-x} \mathrm{O}\right.$ with $0.05<x<0.18$ ). In $\mathrm{ABO}_{3}$ perovskite oxides, non-stoichiometry arises from a cation deficiency in $\mathrm{A}$ or $B$ sites $\left(\mathrm{A}_{x} \mathrm{WO}_{3}\right.$, $\mathrm{A}$ being an alkali ion) or oxygen anions excess. Cation A has a great influence on electrical properties. For instance, $\mathrm{WO}_{3}$ is an insulator, while $\mathrm{A}_{x} \mathrm{WO}_{3}$ is a semiconductor at low $x$ values and metallic at high $x$ values. Oxygen-deficient perovskites have attracted much attention because of their oxygen storage ability and their redox properties, quite useful for total oxidation reactions. In fully oxidised $\mathrm{CaMnO}_{3-\delta}$ and $\mathrm{CaFeO}_{3-\delta}$ perovskites, $\mathrm{Mn}$ and $\mathrm{Fe}$ are at +4 oxidation state and $\delta=0$, the material can accommodate up to $17 \%$ oxygen vacancies without loosing its structure. The $\mathrm{Sr}_{1-x} \mathrm{La}_{x} \mathrm{Co}_{1-y} \mathrm{Fe}_{y} \mathrm{O}_{3-\delta}$ series, with brownmillerite-type oxygen defects, exhibit high electronic/oxygen ion mobilities. In some perovskites a small oxygen excess can be accommodated by the formation of cation vacancies at A- or B-sites, leaving the oxygen sub-lattice intact. Electronic defects may be created upon reduction and oxidation of metal cations at different 
oxygen partial pressures $\left(p_{02}\right)$. At low $p_{02}$, the material loses oxygen, which generates electrons, enhancing the n-type conductivity, according to $\mathrm{O}_{0} \leftrightarrow(1 / 2) \mathrm{O}_{2}+\mathrm{V}_{0} \cdot \boldsymbol{*}+2 \mathrm{e}^{-}$. At high $p_{02}$, oxygen is incorporated into an oxygen vacancy and takes two electrons from the valence band, leading to holes contributing to the p-type conduction, according to $(1 / 2) \mathrm{O}_{2}+$ $\mathrm{V}_{0} \cdot \bullet \leftrightarrow \quad \mathrm{O}_{0}+2 \mathrm{~h}^{\bullet}$. A consequence of the trapping of electronic defects is that the solid becomes insulating at low temperatures. Defect associations between oxygen vacancies and acceptor dopants are observed in $\mathrm{Y}_{-} \mathrm{ZrO}_{2}$, where $\mathrm{V}_{0}{ }^{\bullet}$ are trapped by $\mathrm{YZr}^{\bullet}$ defects, leading to a drastic decrease in oxide ion conductivity.

Protonic defects, associated with acceptor dopants, limit protonic conduction in metal oxides. As all metal oxides contain impurities, the defect mechanism of "pure" oxides is similar to that of doped oxides. For instance, strontium titanate, $\mathrm{SrTiO}_{3}$, has a similar defect chemistry to acceptor-doped $\mathrm{SrTiO}_{3}$ because the impurities are ions at lower oxidation states such as $\mathrm{Fe}^{3+}, \mathrm{Al}^{3+}, \mathrm{Mg}^{2+}$, and $\mathrm{Na}^{+}$, and their concentrations, typically ca. $10^{2}-10^{3} \mathrm{ppm}$, are sufficient to dominate the defect chemistry, especially at high $p_{02}$. All these aspects should be taken into account when considering the reaction mechanisms and kinetics on metal oxide catalysts, for instance in selective or total oxidation reactions on mixed metal oxides, where electron and oxygen anion mobilities and lattice oxygen diffusion or storage capacity are important, for instance in a redox or in total catalytic oxidation reactions.

Polyoxometallates (POMs) constitute a large class of nanosized transition metal-oxygen clusters intermediate between molecules and oxides [7]. They are formed of anions of metal-oxygen octahedra as basic structural units, linked together to constitute a stable and compact skeleton of polymeric oxoanions, as shown in the equation:

$p\left[\mathrm{XO}_{r}\right]^{x-2 r}+q\left[\mathrm{MO}_{n}\right]^{m-2 n}+z \mathrm{H}^{+} \rightarrow \mathrm{X}_{p} \mathrm{M}_{q} \mathrm{O}_{x}(p \cdot x+m \cdot q-z . s)+(z / 2) \mathrm{H}_{2} \mathrm{O}$

with $\mathrm{M}=$ metal (designated as addenda atom) of valency $m$, $\mathrm{X}=$ heteroatom of valency $x$, and $\mathrm{s}=$ the oxygen balance. The most common $\mathrm{M}$ atoms are Mo and $\mathrm{W}$ and less frequently $\mathrm{Ta}, \mathrm{V}$, $\mathrm{Nb}$ as $d^{0}$ element. There are more than 20 structures incorporating 4 to 40 metal atoms and 1 to 9 heteroatoms. One distinguishes the structures of "Linqvist" $\left[\mathrm{M}_{6} \mathrm{O}_{19}\right]^{n-}\left(\mathrm{O}_{\mathrm{h}}\right.$ symmetry of $6 \mathrm{MoO}_{6}$ edge-shared octahedra), "Keggin" $\alpha-\left[\left(\mathrm{XO}_{4}\right) \mathrm{M}_{12} \mathrm{O}_{36}\right]^{n-}\left(\mathrm{T}_{\mathrm{d}}\right.$ symmetry of $4 \mathrm{M}_{3} \mathrm{O}_{13}$ groups of $3 \mathrm{MO}_{6}$ octahedra), "Dawson" $\alpha-\left[\left(\mathrm{XO}_{4}\right)_{2} \mathrm{M}_{12} \mathrm{O}_{54}{ }^{n-}\left(\mathrm{D}_{\mathrm{h}}\right.\right.$ symmetry of 2 Keggin fragments $\left.\alpha-\mathrm{XM}_{9} \mathrm{O}_{34}\right)$, "Anderson" $\left[\mathrm{H}_{x}\left(\mathrm{XO}_{6}\right) \mathrm{O}_{18}\right]^{n-}\left(\mathrm{D}_{3 \mathrm{~h}}\right.$ symmetry planar arrangement of 7 edge-shared $\mathrm{MO}_{6}$ octahedra), and $\left(\mathrm{XO}_{12}\right) \mathrm{M}_{12} \mathrm{O}_{30}$ structure ( $\mathrm{I}_{\mathrm{h}}$ symmetry with an $\mathrm{XO}_{12}$ icosahedron surrounded by 6 equivalent $\mathrm{M}_{2} \mathrm{O}_{9}$ groups of face shared $\mathrm{MO}_{6}$ octahedra, linked by corner sharing tetravalent cations). The most common POMs used in catalysis are Keggin-type either as acid-base catalysts such as heteropolyacids (HPA) or as redox (for partial oxidation reactions) catalysts. Their properties are controlled, among a large range, by varying the chemical composition, e.g. changing the $\mathrm{M}$ element as in $\mathrm{H}_{3+x} \mathrm{PVV}_{x} \mathrm{MVI}_{12-x} \mathrm{O}_{40}$, the support, the extent of hydration and thermal treatment. For acid samples the following order of acidity range has been established [8]: $\mathrm{H}_{3} \mathrm{PW}_{12} \mathrm{O}_{40}>\mathrm{H}_{4} \mathrm{SiW}_{12} \mathrm{O}_{40} \sim \mathrm{H}_{4} \mathrm{GeW}_{12} \mathrm{O}_{40}>\mathrm{H}_{3} \mathrm{PMo}_{12} \mathrm{O}_{40}>$
$\mathrm{H}_{4} \mathrm{SiMo}_{12} \mathrm{O}_{40} \sim \mathrm{H}_{4} \mathrm{GeMo}_{12} \mathrm{O}_{40}$. Several industrial processes have ben developed, in particular in Japan, such as hydration of propylene to isopropanol in 1972, oxidation of methacrolein to methacrylic acid in 1982, direct oxidation of ethylene to acetic acid in 1997, and production of ethyl acetate in 2001, among other new processes. Giant heteropoyoxometalate compounds have also been synthesised [9], such as the Bielefeld "wheel" $\left[\mathrm{MoVl}_{126} \mathrm{MoV}_{28} \mathrm{O}_{462} \mathrm{H}_{14}\left(\mathrm{H}_{2} \mathrm{O}\right)_{70}\right]^{14-}$ or a Keplerate capsule superfullerene type $\left[\mathrm{MoV}_{172} \mathrm{MoV}_{60} \mathrm{O}_{372}\left(\mathrm{CH}_{3} \mathrm{COO}\right)_{30}\left(\mathrm{H}_{2} \mathrm{O}\right)_{72}\right]^{42-}$ [10] but with no industrial application yet, to my knowledge. Representations of the main heteropolyoxometalate structures are shown in Fig. 2, and some catalytic reactions are reported in Table 1.

\section{Metal oxide catalyst preparations $[11,12]$}

This section addresses the broad topic of metal oxide syntheses of bulk and supported metal oxide catalysts. It corresponds to three main areas: (1) synthesis of simple metal oxides, (2) synthesis of mixed oxides, and (3) preparation of supported metal oxides. A typical industrial operation for manufacturing catalysts comprises: (1) precipitation at a given $\mathrm{pH}$ or other synthesis processes (e.g., sol-gel, solid-solid, flame hydrolysis, and vapour deposition); (2) hydrothermal transformation; (3) decantation, filtration, centrifugation, and washing; (4) crushing and grinding; (5) forming and/or shaping operations; (6) calcination, activation, and reduction.

Catalyst syntheses are schematically represented by: Chemicals (control impurities) $\rightarrow$ Catalyst precursor (texture) $\rightarrow$ Form (texture, shape attrition resistance) $\rightarrow$ Final catalyst (texture, attrition resistance).

For simple oxides, it is important to control the nature of the solid catalyst, its morphology, textural properties (surface area, porosity), and thermal, chemical and mechanical stabilities. Beside thermal methods, which do not permit a fine control of these parameters, three main preparation routes based on the reactions between water or an organic solvent and inorganic precursors are usually employed, namely aqueous-phase precipitation, sol-gel (hydrolytic and non-hydrolytic) process, solvothermal syntheses in the presence of organic molecules and templating procedures resulting in materials with controlled morphology and textural properties, in particular organized microporous, mesoporous, macroporous, and hierarchically-organized oxides. The complexation, solvent-free activated reactive synthesis, allows one to overcome the limited surface area reached after crystallization at high temperature. Organi-

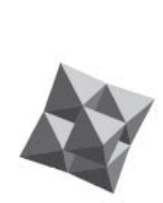

(a)

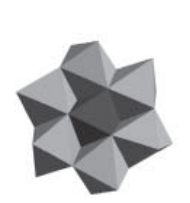

(b)

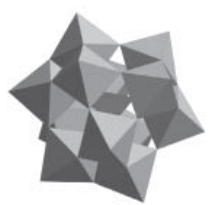

(c)

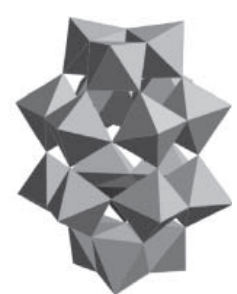

(d)
Fig. 2. Types of polyoxometalates formed by different arrangements of $\mathrm{MO}_{6}$ octahedra. (a) Lindqvist; (b) Anderson; (c) Keggin; (d) Dawson. 
Table 1

Some heterogeneous acid and selective oxidation reactions catalysed by heteropolyacids (HPAs).

\begin{tabular}{|c|c|c|}
\hline Catalyst & Reaction & Specific features \\
\hline $\mathrm{H}_{3} \mathrm{PW}_{12} \mathrm{O}_{40}$ & $\mathrm{CH}_{3} \mathrm{COOH}+\mathrm{C}_{2} \mathrm{H}_{5} \mathrm{OH} \rightarrow \mathrm{CH}_{3} \mathrm{COOC}_{2} \mathrm{H}_{5}+\mathrm{H}_{2} \mathrm{O}$ & $T=150^{\circ} \mathrm{C}$, selectivity $91 \%$ at $90 \%$ conversion \\
\hline $\mathrm{H}_{3} \mathrm{PW}_{12} \mathrm{O}_{40}$ & Alkylation of aromatics & $T=30-100^{\circ} \mathrm{C}$ \\
\hline $\mathrm{Cs}_{2.5} \mathrm{H}_{0.5} \mathrm{PW}_{12} \mathrm{O}_{40}$ & Alkylation of isobutane by butene & $T=20-40^{\circ} \mathrm{C}$ \\
\hline $\mathrm{Pd}_{1.5} \mathrm{PW}_{12} \mathrm{O}_{40}$ & Isomerisation of alkanes & $T=210^{\circ} \mathrm{C}$ \\
\hline $\mathrm{H}_{3} \mathrm{PW}_{12} \mathrm{O}_{40}$ & $\mathrm{CH}_{3} \mathrm{OH}\left(\mathrm{CH}_{3} \mathrm{OCH}_{3}\right) \rightarrow \mathrm{C}_{1}-\mathrm{C}_{6}$ hydrocarbons & $T=300^{\circ} \mathrm{C}$ \\
\hline $\mathrm{Cs}_{2.5} \mathrm{H}_{0.5} \mathrm{PW}_{12} \mathrm{O}_{40}$ & Isobutene + methanol $\rightarrow$ methyl isobutyl ether & $T=290{ }^{\circ} \mathrm{C}$, selectivity $\left(\mathrm{C}_{2}-\mathrm{C}_{4}\right.$ alkenes $) 74 \%$ \\
\hline $\mathrm{H}_{6} \mathrm{P}_{2} \mathrm{~W}_{18} \mathrm{O}_{62}$ & Benzene $+\mathrm{HNO}_{3} \rightarrow$ nitrobenzene & $T=50^{\circ} \mathrm{C}$ \\
\hline $\mathrm{CsH}_{3} \mathrm{PMo}_{11} \mathrm{~V}_{1} \mathrm{O}_{40}$ & Methacrolein to methacrylic acid & $T=280^{\circ} \mathrm{C}, 80 \%-85 \%$ selectivity \\
\hline $\mathrm{H}_{3} \mathrm{PMo}_{12} \mathrm{O}_{40}$ & Isobutane to methacrylic acid & $T=350{ }^{\circ} \mathrm{C}, 45 \%$ selectivity \\
\hline $\mathrm{H}_{5} \mathrm{PMo}_{10} \mathrm{~V}_{2} \mathrm{O}_{40}$ & Isobutyric acid to methacrylic acid & $T=300{ }^{\circ} \mathrm{C}, 72 \%$ selectivity, $52 \%$ conversion \\
\hline $\mathrm{H}_{5} \mathrm{PMo}_{10} \mathrm{~V}_{2} \mathrm{O}_{40}$ & Pentane to phthalic + maleic anhydrides & $T=310^{\circ} \mathrm{C}, 55 \%$ selectivity in $\mathrm{MA}$ \\
\hline
\end{tabular}

zation of the porosity by hard or colloidal templating is a recent approach to maximise the specific surface area leading to mesoporous and hierarchical porosity materials.

The preparation of mixed oxide catalysts involves co-precipitation of two or more mixed salts in solution at a given $\mathrm{pH}$, followed by classical heat treatments. One can also proceed by solid-solid interaction between both salts at high temperature.

Industrially one usually employs either bulk catalysts composed of active components but with some inert binder added (e.g. silica, alumina, silica-alumina) to aid the forming and/or shaping operation and to avoid important attrition, mainly in moving/fluidized bed reactors. This is the case, for instance, for silica-alumina for cat-cracking, copper and chromium oxide for the water gas shift (WGS) reaction, iron molybdate for the oxidation of methanol to formaldehyde, vanadyl pyrophosphate for butane oxidation to maleic anhydride, etc. A description of some structural components of some catalysts are shown in Fig. 2. However, in some cases, bulk catalysts are used as prepared, without the need for addition of the binder. Typically, this involves catalysts prepared by high temperature fusion, e.g., the iron-based ammonia synthesis catalyst. A schematic representation of the influence of preparation parameters is given in Fig. 3.

\section{Main domains of catalytic reactions using metal oxides} [2]

The main domains of heterogeneous catalysis by metal oxides cover acid, base, acid-base (bifunctional), selective oxidation reactions, total oxidation reactions and combustion, photocatalysis and biomass conversion. The first three domains have been described in detail in many reviews or books (see Refs. 1-3) and will not be discussed here. The main catalysts have been described above and include silica, alumina, silica-alumina, acid or base zeolites, polyoxometalates (POMs), hydrotalcites, haxaaluminates, perovskites, etc. The selective oxidation domain is very important and has been described in many papers and books [13]. It deals with transition metal ion oxides exhibiting redox properties, such as $\mathrm{V}, \mathrm{Mo}, \mathrm{Cr}, \mathrm{Te}, \mathrm{Sb}, \mathrm{Bi}$, and $\mathrm{Fe}$, and usually proceeding via the famous Mars and van Krevelen mechanism [14]. In this mechanism shown in Scheme 1 and illustrated in Fig. 4, the lattice oxygen anions $\mathrm{O}^{2-}$ are incorporated into the hydrocarbon and give aldehydes or carboxylic acids or $\mathrm{H}_{2} \mathrm{O}$, leading to a reduction of the catalyst. The corresponding vacancy created is then replenished by gaseous oxygen in the re-oxidation step.

(VO) ${ }_{2} \mathrm{P}_{2} \mathrm{O}_{7}$ for butane to maleic anhydride, multicomponent $\mathrm{Bi}$ molybdate $+\mathrm{Co}(\mathrm{Fe}) \mathrm{MoO}_{4}$ for propene to acrolein, $\mathrm{MoVTeNb}(\mathrm{Sb})-\mathrm{O}$ for propane direct ammoxidation to acrylonitrile or oxidation to acrylic acid, and MoV-O for acrolein oxidation to acrylic acid are among the most important catalysts used industrially [15], as described in Section 7 below and assembled in Tables 2-4.

In the case of catalytic partial oxidation reactions mixed metal oxides based catalysts are mainly on $\mathrm{V}$ and Mo cations attached to other redox cations such as $\mathrm{Sb}, \mathrm{Nb}, \mathrm{Te}$, and $\mathrm{Ta} . \mathrm{V}_{2} \mathrm{O}_{5}$ and $\mathrm{MoO}_{6}$ octahedra are assembled as shown in Fig. 1 and are often composed of several phases acting synergetically between them and giving complex chemical compositions. For instance, this is the case of the mixture of M1 and M2 phases in

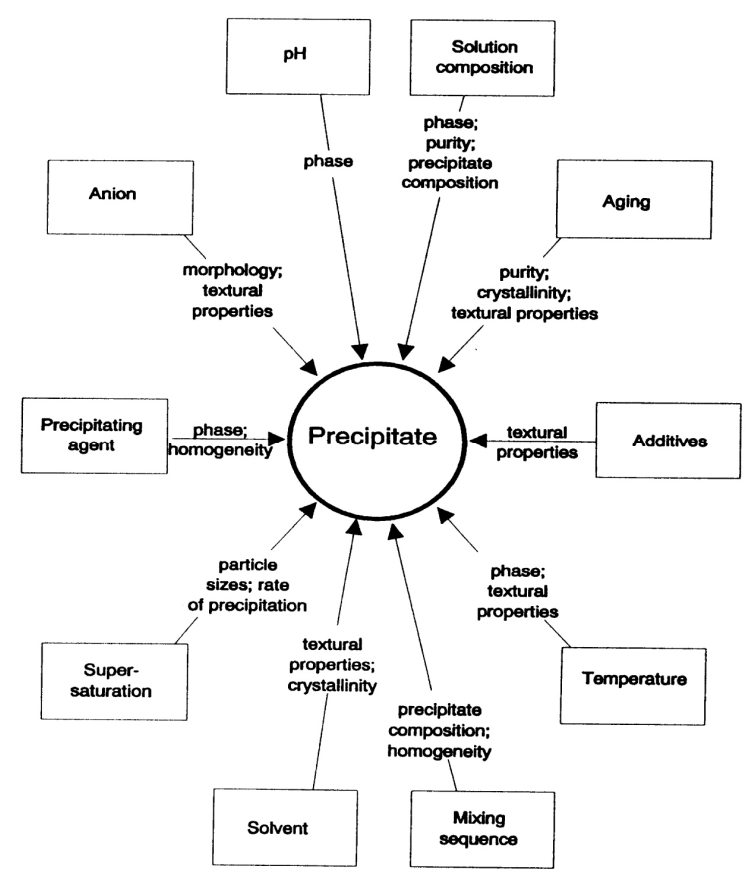

Fig. 3. Parameters affecting the properties of the final precipitation. 


$$
\begin{gathered}
2[\text { CatO }]+\mathrm{R}-\mathrm{CH} \rightarrow 2 \text { [Cat }]+\mathrm{R}-\mathrm{C}-\mathrm{O}+\mathrm{H}_{2} \mathrm{O} \\
2 \text { [Cat }]+\mathrm{O}_{2} \text { (gas) } \rightarrow 2 \text { [CatO] }
\end{gathered}
$$

Scheme 1. The Mars and van Krevelen mechanism, where [CatO] represents the oxidised catalyst surface, [Cat] its reduced state, $r_{\text {red }}$ the rate of catalyst reduction by a reactant, $r_{\mathrm{ox}}$ the rate of its re-oxidation by co-fed oxygen, $\mathrm{R}-\mathrm{CH}$ and $\mathrm{R}-\mathrm{C}-\mathrm{O}$ the reactant and the product. The relative rates of $r_{\text {red }}$ and $r_{\text {ox }}$ determine the selectivity in the product and involve lattice oxygen anions, which may be incorporated into the reactant. If $k_{\text {red }} p_{\mathrm{HC}}>k_{\mathrm{ox}} p_{02}$, re-oxidation of the surface is the rate-determining step; if $k_{\text {red }} p_{\mathrm{HC} \ll} k_{0 x} p_{02}$, reduction of the surface is the rate-determining step. Thus reoxidisability and reducibility of the catalyst will lead to different kinetic expressions. Note that for partial oxidation reactions on transition metal oxides vanadium element has appeared as a key element, acting as schematised in Fig. 4.

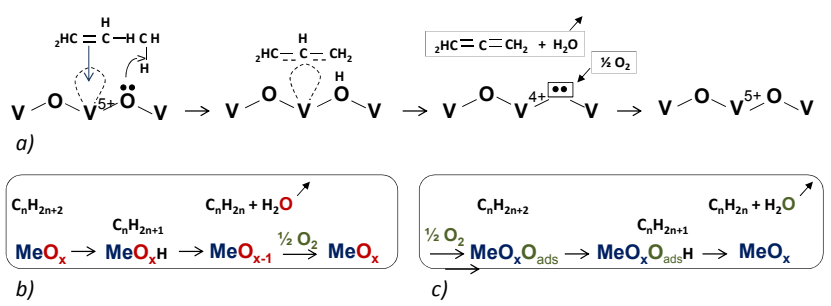

Fig. 4. Simplified schemes of (a) propene adsorption on $\mathrm{O}-\mathrm{V}-\mathrm{O}$ and formation of a $\pi$-allyl complex intermediate, (b) the case of an alkane, and (c) the effect of adsorbed oxygen.

the MoVTeNb-O catalyst used for propane amm/oxidation to acrylonitrile/acrylic acid.

In these partial oxidation reactions, the selectivity to the desired compounds (olefins, aldehydes, carboxylic acids, nitriles, etc.) depends on the nature of surface oxygen anions $\left(\mathrm{O}^{2-}\right)$ being nucleophilic (selective) or nucleophilic (non selective) associated to the cation(s) $\mathrm{Me}^{n+}$, on Me-O bond energy and their distribution on the surface. This may come from the fact that oxidation reactions are demanding, i.e., are structure-sensitive [4], when the number of electrons involved in the reaction is high. For instance, many catalysts are able to transform propane to propylene (reaction with $2 \mathrm{e}^{-}$), whereas only three (Cu-O, Bi-Mo-O, Sn-Sb-O) are able to transform propylene to acrolein (4e- reaction) and only one ((VO) $\left.{ }_{2} \mathrm{P}_{2} \mathrm{O}_{7}\right)$ to oxidise butane to maleic anhydride (a $14 \mathrm{e}^{-}$reaction) or


reaction.

\section{Biomass transformation reactions [16-18]}

From the view point of chemicals and energy resources, utilization of the resources other than fossil resources is important in overcoming the environmental issues and for building a sustainable society. One of the possibilities for chemicals is biomass, in particular cellulosic biomass. Solid acids and bases should play important roles in conversion. Actually, the conversions of biomass and biomass-derived products have been studied extensively in recent years. Among them, biodiesel synthesis and utilization of glycerol are important topics $[19,20]$, though only one process has been industrialized for biodiesel production on $\mathrm{ZnO}-\mathrm{Al}_{2} \mathrm{O}_{3}$ catalysts. Note that the solid acids and bases applicable to biomass conversions should be water-tolerant catalysts [21,22].

Table 2

\begin{tabular}{|c|c|}
\hline Catalyst & Important applications \\
\hline $\mathrm{SiO}_{2}-\mathrm{Al}_{2} \mathrm{O}_{3}$ & Acid-catalysed reactions, e.g., FCC, isomerisation \\
\hline $\mathrm{Fe}_{2} \mathrm{O}_{3}$ & Fisher-Tropsch reaction, ethyl benzene oxidehydrogenation to styrene \\
\hline $\mathrm{TiO}_{2}, \mathrm{CeO}_{2}$ & Major component of deNO ${ }_{x}$ catalysts \\
\hline $\mathrm{ZrO}_{2}-\mathrm{SO}_{4}{ }^{2-}$ & Strong acid reactions \\
\hline $\mathrm{Cu}-\mathrm{ZnO} / \mathrm{Al}_{2} \mathrm{O}_{3}$ & Methanol synthesis from $\mathrm{CO}+\mathrm{H}_{2}$ \\
\hline$(\mathrm{VO})_{2} \mathrm{P}_{2} \mathrm{O}_{7}$ & Selective oxidation of butane to maleic anhydride, Oxidation of pentane to phtalic anhydride + maleic anhydride \\
\hline Cu-Cr oxides & Hydrogenations, combustion reactions \\
\hline Sn-Sb oxides & Selective oxidations, e.g. propene to acrolein or isobutene to methacrolein \\
\hline Bi molybdates & Propene selective oxidation/ammoxidation to acrolein/acrylonitrile \\
\hline V-Mo oxide & Selective oxidation of acrolein to acrylic acid \\
\hline MoVTeNb oxide & Selective direct amm/oxidation of propane to acrylonitrile/acrylic acid \\
\hline
\end{tabular}

Some industrial catalysts prepared by precipitation, coprecipitation techniques.

Table 3

\begin{tabular}{|c|c|}
\hline Catalyst & Important applications \\
\hline $\mathrm{V}_{2} \mathrm{O}_{5}, \mathrm{~V}_{2} \mathrm{O}_{5} / \mathrm{TiO}_{2}, \mathrm{~V}_{2} \mathrm{O}_{5}-\mathrm{WO}_{3} / \mathrm{TiO}_{2}$ & Selective catalytic reduction of $\mathrm{NO}_{x}$ \\
\hline $\mathrm{Nb}_{2} \mathrm{O}_{5} / \mathrm{SiO}_{2}$ & Isomerisation of $n$-butene \\
\hline $\mathrm{Cr}_{2} \mathrm{O}_{3}$ & Fluorination of $\mathrm{C}_{2} \mathrm{Cl}_{3} \mathrm{~F}_{3}$ with $\mathrm{HF}$ \\
\hline $\mathrm{Pt}-\mathrm{Sn} / \mathrm{Al}_{2} \mathrm{O}_{3}$ & n-Heptane dehydrocyclisation, propane dehydrogenation \\
\hline Transition metal $/ \mathrm{Al}_{2} \mathrm{O}_{3}$ & Polymerisation/co-polymerisation of alkenes \\
\hline $\mathrm{Ni}-\mathrm{Mo} / \mathrm{TiO}_{2}-\mathrm{ZrO}_{2}$ & Hydrodesulfurisation of gas-oil \\
\hline $\mathrm{PbO}-\mathrm{ZrO}_{2}, \mathrm{PbO}-\mathrm{Al}_{2} \mathrm{O}_{3}$ & Nitroxidation of alkenes \\
\hline $\mathrm{Li}^{+} / \mathrm{MgO}$ promoted by $\mathrm{Cl}^{-}$ & Oxidative dehydrogenation of ethane \\
\hline $\mathrm{Pt} / \mathrm{TiO}_{2}$ & Oxidation of $\mathrm{CO}$ \\
\hline $\mathrm{Pd} / \mathrm{SiO}_{2}$ & Hydrogenation of phenylacetylene \\
\hline Zeolites & Acid reactions, e.g. FCC, alkanes \& alkenes isomerization, methanol to gasoline (MTG) or to olefins (MTO) \\
\hline $\mathrm{AlPO}_{4}, \mathrm{SAPO}-34$ & Acid-catalysed reactions, polymerisation, methanol to olefins (MTO) \\
\hline
\end{tabular}

Some industrial catalysts prepared by sol-gel or hydrothermal (templated) techniques. 
Table 4

Some industrial processes using metal oxide catalysts or supports.

\begin{tabular}{|c|c|}
\hline Reaction & Catalyst \\
\hline Steam reforming of hydrocarbons to $\mathrm{CO}+\mathrm{H}_{2}$ & $\mathrm{Ni} / \mathrm{Al}_{2} \mathrm{O}_{3}$ \\
\hline Water gas shift $\left(\mathrm{CO}+\mathrm{H}_{2} \mathrm{O} \rightarrow \mathrm{CO}_{2}+\mathrm{H}_{2}\right)$ & Fe oxide or $\mathrm{Zn}, \mathrm{Cu}, \mathrm{Cr}$ mixed oxides \\
\hline Methane dry reforming $\left(\mathrm{CO}_{2}+\mathrm{CH}_{4} \rightarrow 2 \mathrm{CO}+2 \mathrm{H}_{2}\right)$ & $\mathrm{Ni} / \mathrm{Al}_{2} \mathrm{O}_{3}$ \\
\hline Methanol synthesis from $\mathrm{CO}+\mathrm{CO}_{2}+\mathrm{H}_{2}$ & $\mathrm{Cu}-\mathrm{Zn}-\mathrm{O} / \mathrm{Al}_{2} \mathrm{O}_{3}$ \\
\hline Methanol steam reforming $\left(\mathrm{CO}_{2}+3 \mathrm{H}_{2}\right)$ & $\mathrm{Cu}-\mathrm{Zn}-\mathrm{O} / \mathrm{Al}_{2} \mathrm{O}_{3}$ \\
\hline Methanol to hydrocarbons (MTG process) & H-MFI zeolite \\
\hline Methanol to light olefins (MTO process) & SAPO-34 \\
\hline Methanol oxidation to formaldehyde & $\mathrm{Fe}_{2}\left(\mathrm{MoO}_{4}\right)_{3}$ \\
\hline $\mathrm{SO}_{2} \rightarrow \mathrm{SO}_{3}$ for $\mathrm{H}_{2} \mathrm{SO}_{4}$ & $\mathrm{~V}_{2} \mathrm{O}_{5} /$ diatomaceous earth \\
\hline $\mathrm{H}_{2} \mathrm{~S}$ oxidation to $\mathrm{SO}_{2}$ and $\mathrm{H}_{2} \mathrm{SO}_{4}$ & $\mathrm{Fe}_{2} \mathrm{O}_{3} / \mathrm{SiO}_{2}$ or $/ \alpha-\mathrm{Al}_{2} \mathrm{O}_{3}$ \\
\hline$o$-Xylene $+\mathrm{O}_{2} \rightarrow$ phthalic anhydride & $\mathrm{V}_{2} \mathrm{O}_{5} / \mathrm{TiO}_{2}$ (anatase) \\
\hline Metathesis & Re-O, Ru-O \& W-O \\
\hline $\mathrm{C}_{3}-\mathrm{C}_{4}$ alkane dehydrocyclisation to aromatics & Ga-MFI zeolite \\
\hline Selective catalytic reduction of $\mathrm{NO}_{x}$ & $\mathrm{~V}_{2} \mathrm{O}_{5}+\left(\mathrm{WO}_{3}\right.$ or $\left.\mathrm{MoO}_{3}\right) / \mathrm{TiO}_{2}$ \\
\hline SCR of $\mathrm{NO}_{x}$ at high temperature & $\mathrm{Cu} /$ chabazite zeolite \\
\hline Propene ammoxidation to acrylonitrile & Bismuth molybdate \\
\hline Propane ammoxidation to acrylonitrile & MoVTeNb-O (M1 phase) \\
\hline Propene oxidation to acrolein & Bismuth molybdate \\
\hline Acrolein oxidation to acrylic acid & Mo-V-O \\
\hline Aromatic carboxylic acids hydrogenation to aldehydes & Zirconia \\
\hline Hydrodesulfurization of oil distillates & CoMo-O, NiMo-O, Ni-W-O $/ \gamma-\mathrm{Al}_{2} \mathrm{O}_{3}$ \\
\hline Synthesis gas $\left(\mathrm{CO}+\mathrm{H}_{2}\right)$ to hydrocarbons (fuel range) & Supported Co and Fe catalysts \\
\hline Parafins $\left(\mathrm{C}_{5}-\mathrm{C}_{12}\right)$ isomerization & Supported $\mathrm{W}-\mathrm{O}$ and sulfated $\mathrm{ZrO}_{2}$ \\
\hline Olefin epoxidation & Titanosilicate (TS1) \\
\hline Alkanes $\left(\mathrm{C}_{2}-\mathrm{C}_{5}\right)$ dehydrogenation to olefins & $\mathrm{Cr}_{2} \mathrm{O}_{3} / \mathrm{Al}_{2} \mathrm{O}_{3}$ or $\mathrm{Pt} / \mathrm{Al}_{2} \mathrm{O}_{3}$ \\
\hline Alkanes oxidative dehydrogenation to olefins & V-based catalysts \\
\hline Butane to maleic anhydride & $(\mathrm{VO})_{2} \mathrm{P}_{2} \mathrm{O}_{7}$ \\
\hline Methane oxidative coupling to ethylene & Doped rare earth oxides \\
\hline Ethylene $+\mathrm{HCl}+\mathrm{O}_{2}$ to dichloroethane & $\mathrm{ZnO}, \mathrm{Cr}_{2} \mathrm{O}_{3}, \mathrm{CuO}$ \\
\hline Exhaust gases elimination & Pt-Rh-Pd alloys on oxides \\
\hline
\end{tabular}

Currently, acrolein is produced primarily by the gas-phase oxidation of propylene on multicomponent catalysts (e.g. Bi$\mathrm{FeCoMoO}_{4}$ ). However, as the use of propylene derivatives, particularly polymers, has recently been sharply increased, and since this trend is likely to continue in the foreseeable future, the availability and cost of propylene is going to increase. One approach to substitute propylene relies on the use of new raw materials. For instance, catalysts and processes have been developed for the direct conversion of glycerol to acrolein [23]. However, in such processes/catalyst two major difficulties were observed, namely rapid deactivation and selectivity limited to less than $80 \%$. There is thus a need to develop novel routes for the production of acrolein. One approach could be the conversion of allyl alcohol, which is produced in an initial step either by biomass fermentation or through the dehydration of 1,3-propanediol, or the dehydration/oxidation of glycerol $[24,25]$. The MTO (methanol to olefins, mainly $\mathrm{C}_{2}=$ and $\mathrm{C}_{3}=$ ) has been successfully developed recently in China, using SAPO-34 catalyst [26]. The world first commercial unit of MTO process was constructed and started to operate by Shenhua Group in 2010, which was an important progress for coal to chemicals.

A series of $\mathrm{Mo}_{3} \mathrm{VO}_{x} / \mathrm{H}_{4} \mathrm{SiW}_{12} \mathrm{O}_{40} / \mathrm{Al}_{2} \mathrm{O}_{3}$ catalysts, as bifunctional catalysts, have been prepared and applied for the one-step oxydehydration of glycerol to acrylic acid [27]. It was found that acetic acid was produced in parallel with acrylic acid at similar yield when adjusting $\mathrm{Mo}_{3} \mathrm{VO}_{x}$ content in the catalysts.
Increasing calcination temperature from 350 to $650{ }^{\circ} \mathrm{C}$ led to structural evolution of supported active species and subsequent activity change. Crystallinity of $\mathrm{Mo}_{3} \mathrm{VO}_{x}$ increased with calcination temperature, and a large amount of $(\mathrm{V}, \mathrm{Mo}) \mathrm{O}_{x}$ hetero-polyoxo mixed oxides were formed above $550{ }^{\circ} \mathrm{C}$. The Keggin structure of $\mathrm{H}_{4} \mathrm{SiW}_{12} \mathrm{O}_{40}$ began to dissociate around 450 ${ }^{\circ} \mathrm{C}$, causing the formation of various $\mathrm{WO}_{x}$ species. Above $450{ }^{\circ} \mathrm{C}$, the yield of acrylic acid dropped while that of acrolein reached its maximum value with increase of the catalyst calcination temperature. In contrast, the yield of acetic acid exhibited a minor change. Based on the catalytic and characterization data, possible active centres and reaction pathways have been proposed, while for the improvement of the bi-functional catalyst for the one-step conversion of glycerol, it was proposed that both the acidic and redox properties of catalysts should be finely tuned. The $\left(\mathrm{V}_{0.07} \mathrm{Mo}_{0.93}\right)_{5} \mathrm{O}_{14}$ entities were suggested to be the active species for acrolein oxidation, while isolation of dehydration and oxidation active centres was also suggested to improve acrylic acid yield.

\section{Photocatalysis [28-32]}

Photocatalysis is a relatively young science, which is already of great interest for green and environmental chemistries, as it operates at room temperature and does not need thermal energy, the catalyst being activated by the photons. The technique is able to excite electrons $\mathrm{e}^{-}$from the conduction band or to 
generate electron holes $\mathrm{h}^{+}$in the valence band. The catalysts, simple oxide as $\mathrm{TiO}_{2}$ or doped oxides, sulfides, etc., are polyphasic: solid catalyst, liquid or gaseous reactants and electromagnetic (photons from solar light or UV-rays). The first example was discovered accidently from a thermogravimetric study of oxygen chemisorption on evacuated $\mathrm{TiO}_{2}$, which was observed to lead to different weight increases and colour changes under oxygen, depending on the solar or unsolar day in the laboratory at Claude Bernard University (Lyon-1) in France. The same results were obtained by irradiating the sample with UV light. The pioneers ( $S$. Teichner et al.) took advantage of this labile oxygen $\mathrm{O}^{*}$ species to study at room temperature selective oxidation of alkanes $\mathrm{C}_{n} \mathrm{H}_{2 n+2}$ (with $n \geq 2$ ) to the corresponding aldehydes and extended further to the oxidation of cycloalkanes, alkenes, substituted aromatics, amines, etc. Electrical photoconductivity experiments have shown that oxygen is photoadsorbed as ionic $\mathrm{O}_{2}^{-}$and $\mathrm{O}^{-}$species [33], $\mathrm{O}^{-}$being the precursor of the activated $\mathrm{O}^{*}$ species according to $\mathrm{O}^{-}$ads $+\mathrm{h}^{+} \rightarrow$ $\mathrm{O}^{*}$ ads. In presence of water (gas or liquid) adsorbed $\mathrm{H}_{2} \mathrm{O}$ molecules dissociate to $\mathrm{OH}^{-}$ads and $\mathrm{H}^{+}$ads and $\mathrm{OH}^{-}$ads $+\mathrm{h}^{+} \rightarrow \mathrm{OH}^{\circ}$ ads radical, which is very nucleophilic and thus non-selective in oxidation reactions. This aspect has led to the use of photocatalysis for pollution abatement of organic compounds such as pesticides, in particular organophosphorous compounds as phenitrothion $\left[\left(\mathrm{CH}_{3}\right)_{2}-\mathrm{P}(=\mathrm{S})-\mathrm{O}-\mathrm{C}_{6} \mathrm{H}_{3}\left(\mathrm{NO}_{2}\right)-\mathrm{CH}_{3}\right]$ or dyes.

Among all the semiconductor materials under investigation, metal oxides represent the most important candidates due to their unique physiochemical properties. Producing hydrogen fuel via photocatalytic water splitting on semiconductor materials has attracted intense interest in the past decades due to its potential to address important energy and environmental problems. As the main sector for implementing photocatalytic reactions, semiconductor materials have been the focus of the research efforts.

Since the report of using $\mathrm{TiO}_{2}$ for photoelectrochemical water splitting, metal oxide-based semiconductors have received great attention in the field of solar energy conversion. In particular, significant advances have been achieved on using metal oxide semiconductors for photocatalytic water splitting reactions. The objective is the development of novel metal oxide-based photocatalysts with appreciable solar light absorption and electronic properties. The tuning of the electronic structures of existing photocatalysts to obtain enhanced light absorption and more efficient charge separation and transportation has been intensively studied. However, there is still a huge gap between the actual solar-to-hydrogen (STH) efficiency achieved and the theoretical maximal value. Currently, the highest STH efficiency achieved on metal oxide photocatalysts is only $c a .1 \%$, which is far away from what is required for any practical application. Therefore, there is still a long way to go before the large-scale application of photocatalytic water splitting for solar energy conversion. In the future, efforts should be devoted to the development of metal oxides with wide solar light absorption and appropriate band edge positions for water splitting. Recently, MIL-101 (Fe) particles have been coated with an amorphous shell of titania and were observed [34] to lead to hydrogen production from water using visible light, while neither component alone was able to do it.

\section{Industrial applications of metal oxides [35]}

Industrial applications of metal oxide catalysts cover mainly the synthesis of petrochemicals (chemical intermediates such as acrylonitrile, maleic anhydride, acrolein, acrylic acid, and substituted aromatic compounds) [36], in which the $V$ element appears as a key partner and for fuel manufacture. Many processes have been developed as summarised in Table 4.

Currently, most of the acrylic acid produced world-wide is made using the same process, namely the two-stage oxidation of propylene. In this process, propylene is oxidised to acrolein in a first reactor on scheelite Bi molybdate-based catalyst (defect structure of scheelite $\left(\mathrm{Bi}_{2 / 3} \square 1 / 3 \mathrm{Mo}_{3} \mathrm{O}_{12}\right.$, where $\square$ represents a cation vacancy in the ideal $\mathrm{ABO}_{4}$ structure) containing Co and Fe molybdates [37], and acrolein is further oxidised to acrylic acid in a second reactor without intermediate separation. The second stage catalysts are MoVWCu-O mixed oxides as key formulation. These catalysts are mostly X-ray amorphous and contain $V$ in a reduced state.

It was observed that an oxide catalyst consisting of molybdenum, vanadium and niobium was able of yield high conversion of ethane and high selectivity to both ethylene and acetic acid products [38]. The best catalyst was found to be $\mathrm{Mo}_{0.61} \mathrm{~V}_{0.31} \mathrm{Nb}_{0.08}$. Further, two defect oxide structures of molybdenum and vanadium were identified as the likely catalysts for the selective oxidation of ethane. These two phases are uniquely described by the stoichiometry $\mathrm{Mo}_{4} \mathrm{~V}_{6} \mathrm{O}_{25}$ and $\mathrm{Mo}_{6} \mathrm{~V}_{9} \mathrm{O}_{40}$ with the inclusion of niobium to stabilise the structure and promote microcrystallinity. Propane direct oxidation to acrylic acid has been studied [39] on mixed oxides, such as MoVTe(Sb)Nb-O of structure derived from the above one MoVNb-O for ethane to ethylene, as well as the dehydration of lactic acid and 3-hydroxypropionic but have not been commercialised yet. Recently, a crucial discovery [40] was the calcination of the mixed oxide, which was previously done in air at around $350{ }^{\circ} \mathrm{C}$, in a non-oxygen containing (i.e. inert) atmosphere (nitrogen gas) at around $620^{\circ} \mathrm{C}$. This resulted in acrylonitrile yields of up to 59\% (92\% propane conversion; $64 \%$ acrylonitrile selectivity), which made the system competitive with the previous processes starting from propene. The active phase was identified as the so-called M1 phase [41]. Acrylonitrile hydrolysis, as well as the Reppe chemistry to get acrylic acid, has been used in the past but is no longer economically attractive. At variance, direct ammoxidation of propane to acrylonitrile on the same $\mathrm{MoVTe}(\mathrm{Sb}) \mathrm{Nb}-\mathrm{O}$ catalysts has been successively industrialised. Among the disclosed compositions is $\mathrm{Mo}_{1} \mathrm{~V}_{0.4} \mathrm{Te}_{0.2} \mathrm{Nb}_{0.1} \mathrm{O}_{\mathrm{x}}$ with reported per pass yield of acrylonitrile of $c$. $14 \%$ (23\% propane conversion; $61.5 \%$ acrylonitrile selectivity). Yields were improved to up to $25 \%$ (58\% propane conversion; $44 \%$ acrylonitrile selectivity) with the addition of various elements as promoters.

Recently glycerol dehydration to acrolein has received much attention to generate a route to renewable acrylic acid. A shift to new reactor technologies, such as microstructured reactors or thermoplate reactors, able to better handle the reaction heat 
triggered the need for more active catalysts. However, currently incremental improvements of the catalyst and process are to be expected, since all the installed capacities are using the same type of technology: multitubular fixed-bed reactors operating slightly above the upper flammability limit, over MoVWCu-mixed oxide catalysts.

The nitrile functionality serves as a useful reactive centre for transformation into a wide spectrum of commercially valuable chemical products, via polymerization, hydrogenation, hydration and condensation, the production of aromatic nitriles using mixed metal oxide catalysts. Commercial application of alkyl aromatic ammoxidation is based on three categories of feedstocks, i.e. toluene, xylenes, and picolines (alkyl pyridines). Catalysts for alkyl aromatic ammoxidation are vanadium oxide based. The ammoxidation reaction produces the corresponding aromatic nitrile. The nitrile products are intermediates for industrially important chemicals including amines, isocyanates for polyurethanes, phthalocyanine dyes and vitamin B compounds (niacin).

An interesting case is the upgrading of methane to ethane by oxidative coupling (OCM), which has led to huge research worldwide since the pioneered early 1970s work by Lunsford at Texas A\&M on Li/MgO-based catalysts. Unfortunately, none industrial processes were developed using such types of catalysts and technology. Recently Siluria Technologies Inc. [42] has developed a process to convert methane to ethylene by OCM. The catalyst is prepared with rare earth oxides either unsupported or supported on $\mathrm{MgO}, \mathrm{CaO}$ or $\mathrm{AlPO}_{4}$ and containing at least two dopants (a metal element, a semi-metal element and a non-metal element). A demonstration plant has been set in La Porte, Texas, and a commercial plant is scheduled for 2019.

\section{Challenges and concluding remarks [43]}

Metal oxide catalysis is a still growing field reflecting the wide range of catalytic reactions involved. It appears that, although great improvements and new developments have been dicovered in the second part of the 20th century, it remains plenty of room for young researchers from academia and industry to discover and develop new metal oxide catalysts and new or improved processes. It can be expected that the first part of the 21st century will see development of new catalysts and development of commercial processes related to environmental issues and legislation constraints.

The challenge of catalysis in the 21st century is to achieve $100 \%$ selectivity of the desired product molecules in uni- or multi-path reactions (designated as "green chemistry") and develop renewable energy-based processes. In catalyst synthesis nanoscience, synthetic methods have been developed to produce monodisperse metal oxide nanoparticles (NPs) in the 0.8-10 $\mathrm{nm}$ range with controlled shape, oxidation states, and composition; these NPs can be used as selective catalysts since chemical selectivity appears to be dependent on all of these experimental parameters. New spectroscopic and microscopic techniques have been developed that analyse and characterise catalysts under reaction conditions and reveal the dynamic change of molecular structure of catalysts and adsorbed molecules as the reactions proceed with changes in reaction intermediates, catalyst compositions at the surface, and oxidation states. Photo water splitting, and methane and carbon dioxide conversion are important research directions in renewable energy conversion.

Let us end this paper by analysis of the current trends in applied heterogeneous catalysis [44]. Since the 1990s major themes of research and developments have emerged, for instance, auto exhaust catalysts for $\mathrm{CO}, \mathrm{NO}_{x}$ and hydrocarbons eliminations from cars and trucks, catalysts for electrochemistry (utilising solar energy with cheap and stable materials, like reduction of water to $\mathrm{H}_{2}$, of $\mathrm{CO}_{2}$ to methanol) and photochemistry (like photo water splitting or solar driven clean-up of environmentally harmful by-products using $\mathrm{TiO}_{2}$ as photocatalyst), quest for enantioselective catalysts by asymmetric sites on heterogeneous catalysts, immobilised transition metal complexes to heterogeneise homogeneous catalysts, immobilised enzymes and cells, catalytic antibodies, catalytic oxidation of widely abundant methane to syngas $\mathrm{CO}+\mathrm{H}_{2}$ and further methanol and onward to hydrocarbon mixtures (MTO and MTG processes), alkane up-grading, in particular by selective partial oxidation, e.g. propane oxidation/ammoxidation to acrylic acid/ acrylonitrile, etc. Some perspectives are summarized in Figs. 5 and 6.

In short, sustainability, efficiency, oil refinery, energy, transport, hydrogen synthesis and stocking, $\mathrm{CO}_{2}$ and $\mathrm{CH}_{4}$ up-grading and catalytic transformations, (e.g. dry reforming), alkanes up-grading to olefins, aldehydes or carboxylic acids, gaseous noxious emissions, greenhouse gases emissions, new

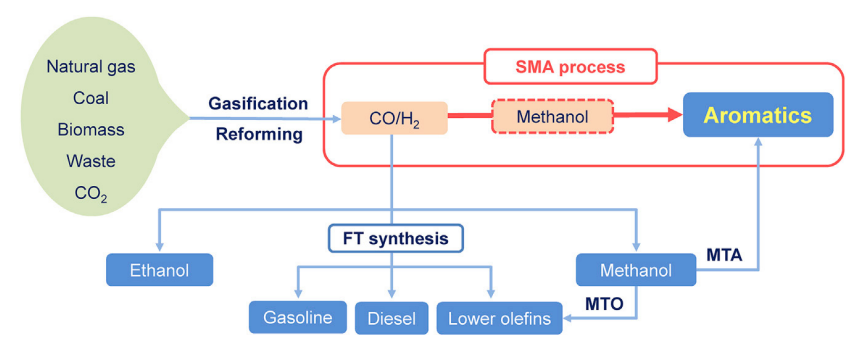

Fig. 5. Typical reaction processes related to syngas chemistry (from Ref [98]). The red-line route demonstrates SMA process for the direct synthesis of aromatics via reaction coupling. FT $=$ Fischer-Tropsch, MTO = methanol to olefins, MTA = methanol to aromatics, SMA = syngas to methanol to aromatics.



Fig. 6. An example of a difficult challenge for the use of carbon dioxide. 
catalysts (e.g. MOFs [45]), new processes, and biocatalysis are, at present, the main drivers in catalysis related R\&D.

\section{References}

[1] J. L. G. Fierro, Metal Oxides: Chemistry and Applications, Taylor \& Francis, Boca Raton, 2006.

[2] S. D. Jackson, J. S. Hargreaves, Metal Oxide Catalysis, Wiley-VCH, Weinheim, 2009.

[3] J. C. Védrine, Metal Oxides in Heterogeneous Catalysis, Elsevier, Amsterdam, 2018.

[4] J. C. Védrine, Catalysts, 2018, 7, 341/1-341/25.

[5] J. C. Volta, J. L. Portefaix, Appl. Catal., 1985, 18, 1-32.

[6] J. Haber, Stud. Surf. Sci. Catal., 1989, 48, 447-467.

[7] J. C. Védrine, J. M. M. Millet, in: S. D. Jackson, J. S. J. Hargreaves (Ed.), Metal Oxide Catalysis, Wiley-VCH, Weinheim, 2009, Chap. 14, 561-594.

[8] I. V. Kozhevnikov, Chem. Rev., 1998, 98, 171-198.

[9] A. Müller, F. Peters, M. T. Pope, D. Gatteschi, Chem. Rev., 1998, 98, 239-272.

[10] P. Gouzerth, M. Che, L'actualié chimique, 2006, 298, 1-14.

[11] X. Carrier, S. Royer, E. Marceau, in: J. C. Védrine (Ed.), Metal Oxides in Heterogeneous Catalysis, Elsevier, Amsterdam, 2018, Chap. 2, 43-103.

[12] G. J. Hutchings, J. C. Védrine, in: M. Baerns (Ed.), Basic Principles in Applied Catalysis, Springer-Verlag Berlin, 2004, 75, 217-258.

[13] D. Duprez, F. Cavani, Handbook of Advanced Methods and Processes in Oxidation Catalysis, From Laboratory to Industry, World Scientific, 2014.

[14] P. Mars, D. W. van Krevelen, Chem. Eng. Sci., 1954, 3, 41-49.

[15] J. L. Dubois, J. J. Brazdil, T. F. Degnan, in: J. C. Védrine (Ed.), Metal Oxides in Heterogeneous Catalysis, Elsevier, Amsterdam, 2018, Chap. 8, 413-549.

[16] A. Corma, M. Renz, H. Susante, Top. Catal., 2009, 52, 1182-1189.

[17] D. Kubička, I. Kubičova, J. Čejka, Catal. Rev. Sci. Eng., 2013, 55, 1-78.

[18] S. Wacławek, V. V. T. Padil, M. Černík, Ecol. Chem. Eng. S., 2018, 25, 9-34.

[19] A. P. S. Chouhan, A. K. Sarma, Renew. Sustain. Energy Rev., 2011, $15,4378-4399$.

[20] Y. C. Sharma, B. Singh, J. Korstad, Fuel, 2011, 90, 1309-1324.

[21] T. Okuhara, Chem. Rev., 2002, 46, 3641-3666.

[22] R. Noma, K. Nakajima, K. Kamata, M. Kitano, S. Hayashi, M. Hara, J.
Phys. Chem. C, 2015, 119, 17117-17125.

[23] P. Lauriol-Garbey, J. M. M. Millet, S. Loridant, V. Bellière-Baca, P. Rey, J. Catal., 2011, 280, 68-76.

[24] S. Sato, R. Takahashi, T. Sodesawa, N. Honda, H. Shimizu, Catal. Commun., 2003, 4, 77-81.

[25] X. Li, Y. Zhang, ACS Catal., 2016, 6, 143-150.

[26] S. Xu, Y. Zhi, J. Han, W. Zhang, X. Wu, T. Sun, Y. Wei, Z. Liu, Adv. Catal., 2017, 61, 37-83.

[27] L. Liu, B. Wang, Y. Du, Z. Zhong, A. Borgna, Appl. Catal. B, 2015, 174-175, 1-12.

[28] M. Formenti, F. Juillet, S. J. Teichner, C. R. Acad. Sci. Paris, 1970, 270, 138-141.

[29] J. M. Herrmann, Catal. Today, 1999, 53, 115-129.

[30] A. L. Linsebigler, G. Q. Lu, J. T. Yates Jr, Chem. Rev., 1995, 95, 735-758.

[31] N. Serpone, G. Sauve, R. Koch, H. Tahiri, P. Pichat, P. Piccinini, E. Pelizzetti, H. Hidaka, J. Photochem. Photobiol. A, 1996, 94, 191-203.

[32] X. Zong, C. Li, in: J. C. Védrine (Ed.), Metal Oxides in Heterogeneous Catalysis, Elsevier, Amsterdam, 2018, Chap. 7, 356-399.

[33] J. M. Herrmann, J. Disdier, P. Pichat, J. Chem. Soc., Faraday Trans. I, 1981, 77, 2815-2832.

[34] K. E. de Krafft, C. Wang, W. Lin, Adv. Mater., 2012, 24, 2014-2118.

[35] T. F. Degnan, in: J. C. Védrine (Ed.), Heterogenous Catalysis by Metal Oxides, Elsevier, Amsterdam, 2018, Chap. 8-3, 503-550.

[36] J. F. Brazdil, in: J. C. Védrine (Ed.), Heterogeneous Catalysis by Metal Oxides, Elsevier, Amsterdam, 2018, Chap. 8-2, 455-502.

[37] J. M. M. Millet, H. Ponceblanc, G. Coudurier, J. M. Herrmann, J. C. Védrine, J. Catal., 1993, 142, 381-391.

[38] E. M.Thorsteinson, T. P. Wilson, F. G. Young, P. H. Kasai, J. Catal., 1978, 52, 116-132.

[39] J. L. Dubois, G. S. Patience, J. M. M. Millet, in: B. Sels, M. van de Voorde (Ed.), Nanotechnology in Catalysis, Applications in the Chemical Industry, Energy Development, and Environmental Protection, Wiley-VCH, Weinheim, 2017, 503-536.

[40] T. Ushikubo, K. Oshima, Jp Patent 5-097431A2, 1992, 116-132.

[41] M. Aouine, J. L. Dubois, J. M. M. Millet, Chem. Comm., 2001, $1180-1181$.

[42] Company Overview, Siluria Technologies Inc., http://siluria.com/About/Company_Overview; Sil Siluria Technologies and Linde announce ethylene technology partnership, The Linde Group, p, https://www.the-linde-group.com/en/news_and_media/press_re

\section{Graphical Abstract}

Chin. J. Catal., 2019, 40: 1627-1636 doi: 10.1016/S1872-2067(18)63162-6

\section{Importance, features and uses of metal oxide catalysts in heterogeneous catalysis}

Jacques C. Védrine *

Sorbonne Université, France

This review aims at assembling the present state of the art of the multiuses of metal oxides in heterogeneous catalysis, concerning liquid and gaseous phases of the reactant mixtures on solid catalysts.




leases/news_20140602.html.

[43] J. C. Védrine, in: J. C. Védrine (Ed.), Metal Oxides in Heterogenous Catalysis, Elsevier, Amsterdam, 2018, Chap. 9, 551-569.
[44] I. Fechete, Y. Wang, J. C. Védrine, Catal. Today, 2012, 189, 2-27.

[45] D. Farrusseng (Ed.), Metal-Organic Frameworks: Applications from Catalysis to Gas Storage, Wiley-VCH, Weinheim, 2011.

\section{金属氧化物催化剂在多相催化中的重要性、特点和应用 \\ Jacques C. Védrine* \\ 索邦大学表面反应实验室, 巴黎, 法国}

摘要: 综述了金属氧化物在多相催化中诸多应用的现状, 涉及固体催化剂上的液相和气相反应混合物, 讨论了金属氧化物 催化剂的主要类型、制备方法和催化的主要反应(酸碱催化、选择性和完全氧化、双功能催化、光催化、生物质处理、环 境催化和某些工业应用), 以及该领域的挑战和前景.

关键词: 多相催化; 金属氧化物催化剂; 制备方法; 酸碱反应; 选择性和完全氧化; 光催化; 环境催化; 工业过程

收稿日期: 2018-06-13. 接受日期: 2018-08-23. 出版日期: 2019-11-05.

*通讯联系人. 电话: +33-668536212,+33-144275560; 电子信箱: jacques.vedrine@sorbonne-universite.fr

本文的电子版全文由Elsevier出版社在ScienceDirect上出版(http://www.sciencedirect.com/science/journal/18722067). 